\title{
THE EFFECT OF ORGANIC AND INORGANIC PHENOLIC COMPOUNDS ON HEMOGLOBIN, HEMATOCRIT, AND CORTISOL HORMONE OF AFRICAN CATFISH (CLARIAS GARIEPINUS)
}

\author{
Saputra Afandi ${ }^{1 *}$, Andayani Sri ${ }^{2}$, Nusyam Happy ${ }^{2}$, Rukmono Djumbuh ${ }^{1}$, \\ Eny Maria Goreti ${ }^{1}$, Mulyono Mugi ${ }^{1}$, Budiani Sri ${ }^{1}$, Suharyadi ${ }^{1}$, Marlina Erni ${ }^{1}$, \\ Nurhudah M. ${ }^{1}$, Thaib Effi A. ${ }^{1}$, Panjaitan Amyda S. ${ }^{1}$, Rahardjo Sinung ${ }^{1}$, \\ Prabowo Guntur ${ }^{1}$, Ilham ${ }^{1}$, Hapsyari Fitriska ${ }^{1}$, Laishevtcev A., \\ ${ }^{1}$ Department of Aquaculture, Jakarta Fisheries University, Indonesia \\ ${ }^{2}$ Faculty of Fisheries and Marine Science, University of Brawijaya, Malang, Indonesia \\ ${ }^{3}$ Federal Scientific Centre VIEV, Moscow, Russia \\ ${ }^{4}$ Laboratory of Biological Control and Antimicrobial Resistance, \\ Orel State University named after I.S. Turgenev, Orel City, Russia \\ *E-mail: afandi.saputra@yahoo.co.id
}

\begin{abstract}
Phenolic are compounds found in the environment which can cause fish stressed or xenobiotic. The limited information about toxicology and pathological consequences in the fish exposed to phenolic compounds needs to be studied. In this research, the African catfish (Clarias gariepinus) were injected a single dose of phenol (inorganic) and P.crocatum Polyphenols (organic). The animals were exposed (75\% of 96 hours LC50) with phenol concentration $(3 \mathrm{mg} / \mathrm{kg}$ ) and P.crocatum Polyphenols $(1.8 \mathrm{mg} / \mathrm{kg})$. Furthermore, the hematology was measured on 3 days after injection. The metabolic effects of hemoglobin and hematocrit decreased significantly $(P<0.05)$ while the cortisol hormone increased $(P<0.05)$ in a short-term after 3 days of exposure.
\end{abstract}

\section{KEY WORDS}

Phenolic, Clarias gariepinus, P. crocatum polyphenols, cortisol, hemoglobin, hematocrit.

Phenolic compounds are xenobiotic compounds that affect anemia and disrupt the endocrine system and hormones (Writer et al., 2010; Hori et al., 2006; Awachie and Ezenwaji, 1998). This compound is classified as toxic chronic and immunotoxic which usually found in fish tissue (Taysse et al., 1995; Mukherjee et al., 1990). Phenol waste is accumulated from human activities such as the waste from industry, pharmaceuticals, and agriculture (Buikema et al., 1979).

The phenol residue comes from industrial and pharmaceutical waste as well as and natural decomposition (Buikema et al., 1979). Red Betel ( $P$. crocatum) is one of the most aromatic plants in which the leaves contain phenolic compounds (flavonoids and tannin) and have a high phenol content (Saputra et al., 2016). Phenolic compounds become a concern specifically because of its toxic effect in the water environment. However, this compound is difficult to detect due to the lack of taste and smell (Tilak et al., 2007). A cytotoxic activity of red betel leaves on Artemia and African catfish was tested in-vivo based on the LC50 and showed that these plants have a potential of cytotoxic compounds. (Nursyam et al., 2017 and Emrizal et al., 2014)

The habitat of Clarias gariepinus is in freshwaters which have a risk to be exposed to chemicals such as phenols (James et al., 2008). Nursyam et al., (2017) and Ibrahem (2012) reported that in-vivo test with an injection of phenolic compounds in fish $C$. gariepinus shows abnormal signs of glucose, BUN, and ALP in the blood and necrosis of liver and kidneys. Even though there is some research on the in-vivo effect of phenolic compounds towards fish blood parameters, there is no information about the residues and effects of organic phenolic compounds from plants to the toxicity on catfish. Therefore, further research is needed to 
determine the in-vivo influence of phenolic compounds of Red Betel Leaf (Piper crocatum) on Hemoglobin, Hematocrit, and Cortisol Hormones of African Catfish (Clarias gariepinus).

\section{MATERIALS AND METHODS OF RESEARCH}

Tested Animal. The African catfish (Clarias gariepinus) used were in the size of 12 to 15 grams. There was 20 fish/tub obtained from the Aquaculture Laboratory of Jakarta Fisheries University. The commercial feed was given twice a day at a dose of $3 \%$. Before the experiment was carried out, the fish was adapted in a concrete tub for 1 month. The quality of DO water conservancy was $3.99-6.53 \mathrm{mg} / \mathrm{l}$ with a $\mathrm{pH}$ of $7.0-7.6$ at $28-30^{\circ} \mathrm{C}$.

Isolation and characterization of Organic and Inorganic phenolic compounds. The organic phenolic compounds used were obtained from the isolation of red betel leaf $(P$. crocatum) using maceration, thin layer chromatography, column chromatography, and characterized by using UV-Vis and Infrared spectrophotometers (Saputra et al. 2016; Bigoniya and Singh, 2014; Sundang et al. 2012; Vasconcelos et al. 2010). The inorganic phenolic compounds were obtained from the commercial chemical store.

Sub-lethal toxicity study. The concentration of LC50 from inorganic phenol $(3 \mathrm{mg} / \mathrm{kg})$ and organic phenolic $(1.80 \mathrm{mg} / \mathrm{kg})$ is equal to $75 \%$ of LC50-96 hours. The exposure to phenolic compounds was done for 3 days after a single injection (Saputra et al. 2016)

Blood sample. The blood was collected 3 days after exposure to phenolic compounds. The blood was taken by using a $1 \mathrm{ml}$ syringe on the cardinal vein and then centrifuged at $3000 \mathrm{rpm}$ at $4^{\circ} \mathrm{C}$ for 15 minutes. The serum was separated and stored at a temperature of 15- $20^{\circ} \mathrm{C}$ (Saputra et al. 2016; Varadarajan et al., 2014; Roche and Boge, 2000). The measurement of hemoglobin level was carried out by the Sahli method (Wedemeyer and Yasutake, 1977) in $\mathrm{Hb} / 100 \mathrm{ml}$ while the hematocrit level was done by the capillary system (Anderson and Siwicki, 1995). On the other hand, the cortisol concentration plasma (Cort) was assessed by radioimmunoassay (RIA) (Foster and Dunn, 1974).

Data analysis. The data were analyzed by using the Analysis of Variance (ANOVA) with Minitab 16 for windows.

\section{RESULTS AND DISCUSSION}

The data analysis showed that the hemoglobin after being exposed with phenolic compounds have a significantly different situation in between the $5 \%$ level of treatment, Fhit: $35.58(P>0.05)$. Based on the Figure 1, the hemoglobin rate of African catfish without treatment (control) is $13.67 \mathrm{Hb} / 100 \mathrm{ml}$ in which it is in line with the research from Alamanda et al., (2007) that a generally healthy African catfish have a hemoglobin level ranged from 12$14 \mathrm{Hb} / 100 \mathrm{ml}$ of blood.

Different conditions indicate that after the hemoglobin is injected, the phenolic compound was significantly decreased in the treatment of organic phenolic that is 7.67 $\mathrm{Hb} / 100 \mathrm{ml}$. In the inorganic phenolic treatment, it is shown that the hemoglobin was lower compared to the treatment of organic phenolic that is $6.67 \mathrm{Hb} / 100 \mathrm{ml}$. According to Nusyam et al., (2017) and Wahjuningrum et al., (2008), low and high hemoglobin levels indicate that the fish might be sick or stressed. Roche and Boge (2000) stated that the increase or decrease in the plasma concentration of hemoglobin is a sign that there is an interference from the cells. Harikrishnan et al., (2003) also asserted that the damage in red blood cells causes a decrease in hemoglobin content.

The results of data analysis showed that the hematocrit condition after being exposed to phenolic compounds was significantly different in between treatments in the level of $5 \%$, Fhit: $17.35(\mathrm{P}>0.05)$. Based on the Figure 2 below, the hematocrit in African catfish without treatment (control) amounts to $37 \%$. This is in accordance with the opinion of Bastiawan et al., (1995) that the normal hematocrit of African catfish is ranged from 30.8 to $45.5 \%$.

The inorganic phenolic treatment showed that the hematocrit value was much lower than the organic treatment which was $23.33 \%$. This value indicates that the treatment of inorganic phenolic greatly affects the decrease in the African catfish hematocrit. Tsuzuki et 
al., (2001) stated that when the fish hematocrit is less than $22 \%$, anemia will occur whereas if the hematocrit is greater than $60 \%$, the fish will be in a state of stress. Anderson and Siwicki (1994) confirmed that low hematocrit can indicate the occurrence of fish contamination.

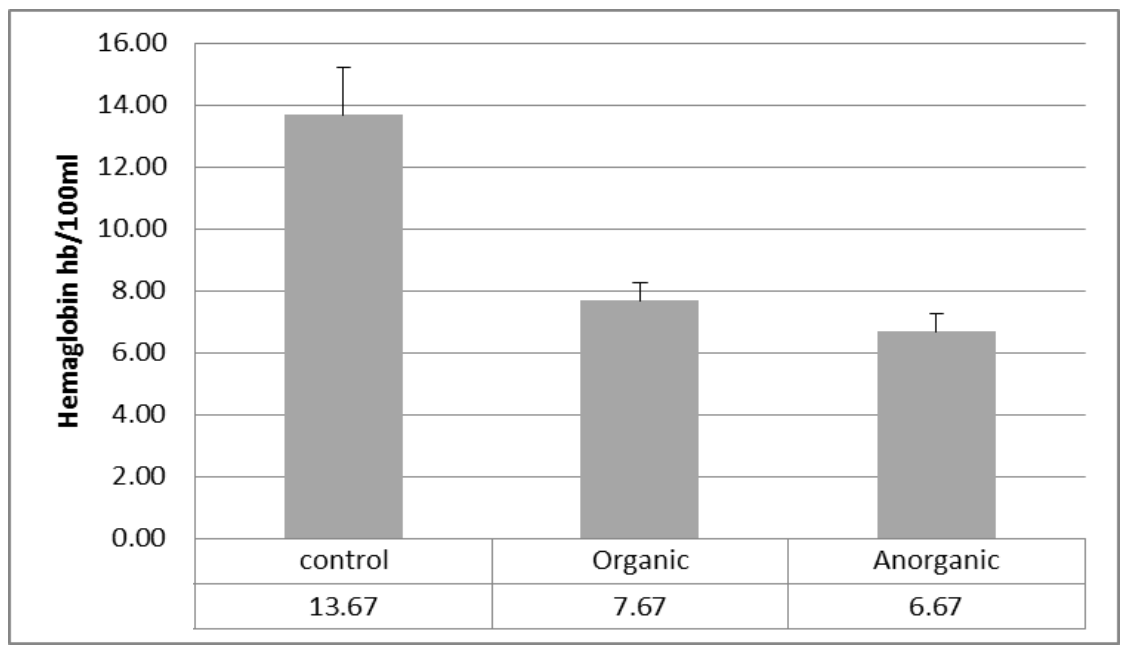

Figure 1 - The Hemoglobin of African Catfish after Organic and Inorganic Phenolic Injection

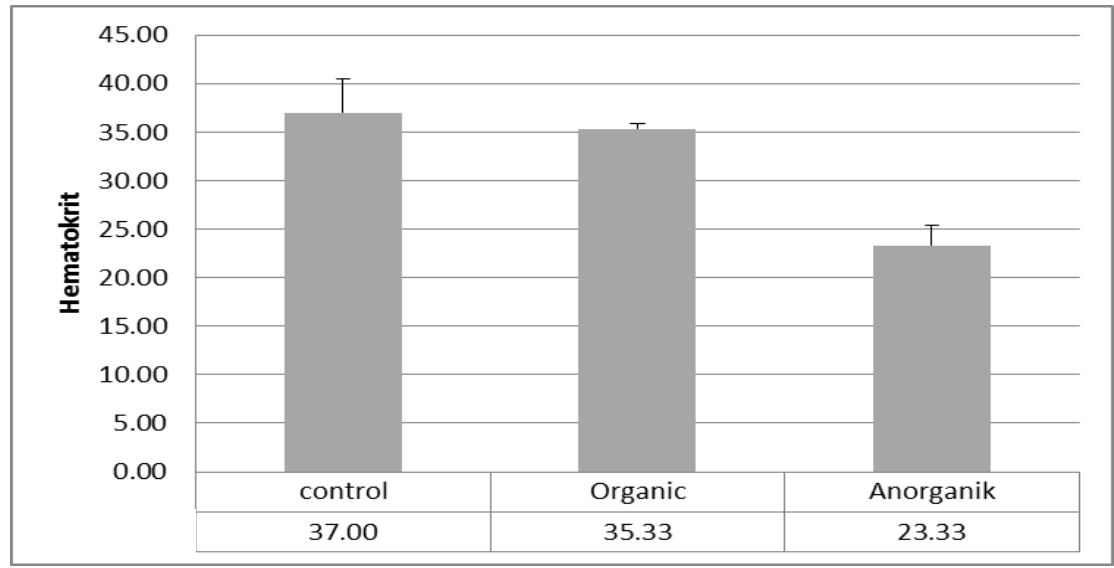

Figure 2 - The Hematocrit of African Catfish after Organic and Inorganic Phenolic Injection

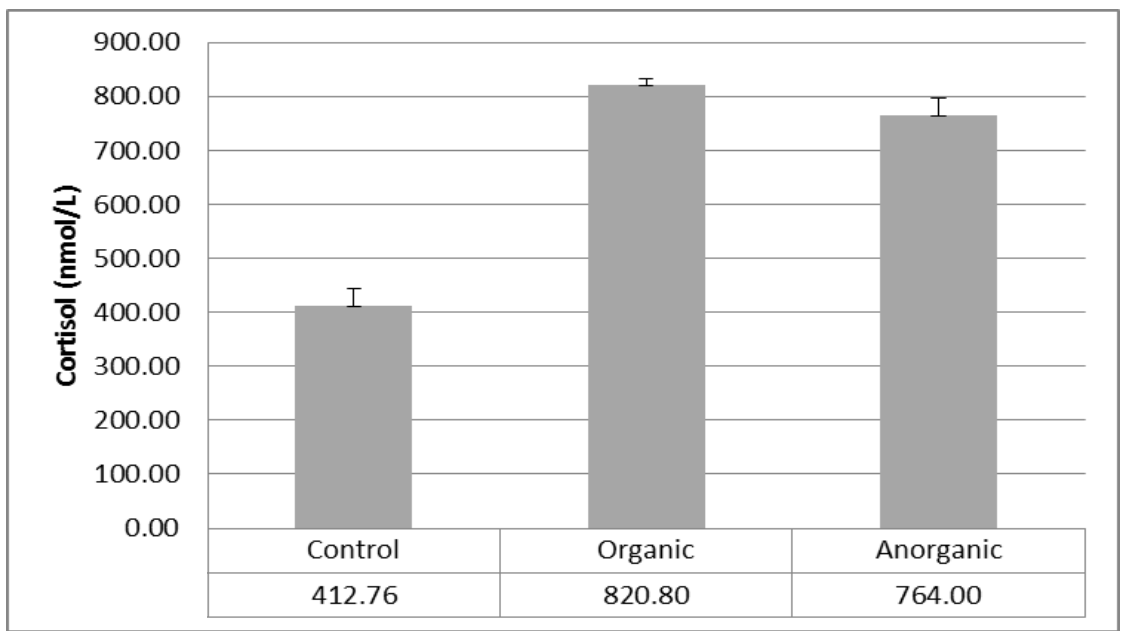

Figure 3 - Cortisol Hormone of African Catfish after Organic and Inorganic Phenolic Injection

This hormone is the result of endocrine gland secretion. The endocrine glands build the endocrine system which has the function of regulating the work of the body's physiological 
processes. The value of the cortisol hormone in catfish after being injected with phenolic compounds can be seen in Figure 3.

The results showed that the cortisol hormone after being exposed to phenolic compounds was significantly different in between the treatments $(5 \%)$, Fhit: 3.86 ( $P>0.05)$. Based on the results of the study, the cortisol in African catfish without treatment (control) is $412.76 \mathrm{nmol} / \mathrm{L}$. The increase of cortisol hormone in phenolic treatment was compared with the control, in which the increase of the hormone was $198.86 \%$ in the organic phenolic treatment and $186.09 \%$ in the inorganic phenol treatment. Roche and Boge (2000) reported that the cortisol hormone in fish treatment was increased by $185.7-218 \%$. According to Zaki et al., (2012), there was an increase in C.gariepinus fish cortisol after being exposed to phenol for 3 months at $32.7 \%$.

John et al., (1994) explained that the increased cortisol in phenol treatment can be associated with fish poisoning and handling. On the one hand, Roche and Boge (2000) believed that the increase in fish stressors after a single or fraction phenol injection is due to the disturbances in cells. The damage to endocrine cells in both liver and kidneys causes an abnormal biochemical blood value that one of which plays a major role in hemoglobin. Low $\mathrm{Hb}$ in tannin injection treatment showed that the spread of oxygen in the body of African catfish was disrupted. Barton (1987) described that a physiological stress will cause a new homeostatic condition in fish through a changing metabolism. This response to stress is controlled by the endocrine system through the release of cortisol hormones and catecholamine.

\section{CONCLUSION}

The results from blood tests show that there is an increase in the cortisol hormone while the other parameters such as hemoglobin and hematocrit experience a decrease. This condition explains that the treatment of organic phenolic exposure is comparable to the inorganic phenol exposure. It can be seen from the changes in the blood hemoglobin and hematocrit as well as the cortisol hormones of African catfish.

\section{REFERENCES}

1. Alamanda, I.E., N.S. Handajani, and A. Budiharjo. 2007. Penggunaan metode hematologi and pengamatan endoparasit darah untuk penetapan kesehatan Ikan Lele Dumbo (Clarias gariepinus) di kolam budidaya Desa Mangkubumen Boyolali. Biodiversitas, (1):34-38.

2. Anderson, D.P., and A.K. Siwicki. 1995. Basic hematology and serology for fish health programs: Fish Health Section, Asian Fisheries Society. 185-202pp.

3. Anderson, D.P., and A.K. Siwicki. 1994. Simplified assays for measuring nonspecific defense mechanisms in fish: Fish Health Section, Fisheries Soc. Meeting. 26 pp.

4. Barton, B.A., C.B. Schreck, and L.D. Barton. 1987. Effects of chronic cortisol administration and daily acute stress on growth, physiological conditions, and stresss responses in juvenile rainbow trout. Diseases of Aquatic Organisms, (2):173-185.

5. Bastiawan, D., Taukhid, M. Alifuddin, and T.S. Dermawati. 1995. Perubahan hematologi and jaringan kan Lele Dumbo (Clarias gariepinus) Yang diinfeksi Cendawan Aphariomyces sp. Jurnal Penelitian Perikanan Indonesia: 106-115.

6. Bigoniya, P., and K. Singh. 2014. Ulcer protective potential of standardized hesperidin, a citrus flavonoid isolated from Citrus sinensis. Rev Bras Farma,(24):330-340.

7. Buikema, Jr.A.L., M.J. Mc. Ginniss, and Jr.J. Cairns. 1979. Phenolics in aquatic ecosystems: a selected review of recent literature. Mar Environ Res, (2):87-181.

8. Emrizal., A. Fernando, R. Yuliandri, K. Rullah, Nola, Indrayani, N.R, Reni, A. Susanty, R. Yerti, F. Ahmad, H.M. Sirat, D. Arbain. 2014. Cytotoxic activities of fractions and two isolated compounds from Sirih Merah (Indonesian red betel), Piper crocatum Ruiz and Pav. Procedia Chemistry, (13):79-84. 
9. Foster, L.B., and R.T. Dunn. 1974. Single antibody technique for radioimmunoassay of cortisol in unextracted serum or plasma. Clin Chem, (20):365-368.

10. Harikrishnan, R., M.N. Rani, and C. Balasundaram. 2003. Haematological and biochemical parameters incommon carp, Cyprinus carpio, following herbal treatment for Aeromonas hydrophilla infection. Aquaculture,221:41-50.

11. Ibrahem. M.D. 2012. Experimental exposure of African catfish Clarias gariepinus (Burchell, 1822) to phenol: Clinical evaluation, tissue alterations and residue assessment. Journal of Advanced Research (3):177-183.

12. James, M.O., L.D. Stuchal, B.A. Nyagode. 2008. Glucuronidation and sulfonation in vitro of the major endocrine-active metabolites of methoxychlor in the channel catfish, Ictalurus punctatus and induction following treatment with 3-methylcholanthrene. Aquatic Toxicology, (2):227-238.

13. John, F., Carragler, and M.R. Christine. 1994. Primary and secondary stress responses in golden pereh Macquoria ambigua. J. comp. Biochem. Physiol, 107A (1):40-56.

14. Mukherjee, D., S. Bhattacharya, V. Kumar, and J. Moitra. 1990. Biological significance of [14C] phenol accumulation in different organs of a murrel, Channa punctatus, and the common carp, Cyprinus carpio. Biomed. Environ. Sci, (3):337-342.

15. Nursyam, H., S. Andayani and A. Saputra. 2017. The effect of tannin from red betel (Piper crocatum) leaves towards blood biochemistry and histology of North African catfish (Clarias gariepinus). AACL Bioflux., Volume 10, Issue 5, pp 1386-1393.

16. Roche, H., and G. Boge. 2000. Fish blood parameters as a potential tool for identification of stress caused by environmental factors or chemical intoxication. Mar. Environ. Res. Part C 125:27-44.

17. Saputra, A., S. Andayani and H. Nusyam. 2016. Total quantity of phenol and isolation methanol tannin extract of red betel leaf (Piper crocatum). International Journal of PharmTech Research. Vol.9, No.7, pp 146-153.

18. Sundang, M, S.N.S. Nasir, C.S. Sipaut, and H. Othman. 2012. Antioxidant activity, phenolic, flavonoid and tannin content of Piper betle and Leucosyke capitella. Malaysian Journal of Fundamental and Applied Sciences. (1):1-6.

19. Taysse, L., D. Troutaud, N.A. Khan, P. Deschaux. 1995. Structure activity relationship of phenolic compounds (phenol, pyrocatechol and hydroquinone) on natural lymphocytotoxicity of carp (Cyprinus carpio). Toxicology, (1-3):207-214.

20. Tilak, K.S., K. Veeraiah, M.S. Butchiram. 2007. Effect of phenol on haematological components of Indian major carps Catla catla, Labeo rohita and Cirrhinus mrigala. J Environ Biol, (2):177-179.

21. Tsuzuki, M.Y., K. Ogawa, C.A. Strussmann. 2001. Physiological responses after stress and subsequent recovery at different salinities in adults pejerrey Odontesthes bonariensis. Aquaculture, 200:349-362.

22. Vasconcelos, P.C.P, M.A. Andreo, W. Vilegas, C.A. Hiruma-Lima, C.H. Pellizzon. 2010. Effect of Mouriri pusa tannins and flavonoids on prevention and treatment against experimental gastric ulcer. Journal of Ethnopharmacology, 131:146-153.

23. Varadarajan, R, H. Sankar H.S, J. Jose and B. Philip. 2014. Sublethal effects of phenolic compounds on biochemical, histological and ionoregulatory parameters in a tropical teleost fish Oreochromis mossambicus (Peters). International Journal of Scientific and Research Publications, (3):2250-3153.

24. Wahjuningrum, D., N. Ashry and S. Suryati. 2008. Pemanfaatan ekstrak daun Ketapang Terminalia Cattapa untuk pencagahan and pengobatan Ikan Patin (Pangasionodon hypophthalmus) yang Terinfeksi (Aeromonas hydrophila). Jurnal Akuakultur Indonesia $7(1): 82-88$.

25. Wedemeyer G.A., and W.T. Yasutake. 1977. Clinical methods for the assessment of the effects of environmental stress on fish health. Technical Paper of the U.S. Fish and Wildlife Service. Vol. 89. U.S. Department of the Interior Fish and Wildlife Service, Washington, D.C., USA. 18p.

26. Zaki, M.S., N. El-Batrawy, and N. M. Taha. 2012. Dose phenol toxicity affected endocrine status in African Catfish (Clarias gariepinus). Life Science Journal, 9(1):636-639. 